\title{
Effects of the essential oil of Lippia gracilis Schauer on caulinary shoots of heliconia cultivated in vitro
}

\author{
ALBUQUERQUE, C.C. ${ }^{1 *}$; CAMARA, T.R. ${ }^{2}$; SANT'ANA, A.E.G. ${ }^{3}$; ULISSES, C. ${ }^{2}$; WILLADINO, L. ${ }^{2}$; MARCELINO \\ JÚNIOR, C. $^{2}$ \\ ${ }^{1}$ Universidade do Estado do Rio Grande do Norte - UERN, Br 110, Km 48 S/N Costa e Silva, CEP 59.600-970, \\ Mossoró-Brasil , 'cycavalcanti@gmail.com ${ }^{2}$ Universidade Federal Rural de Pernambuco - UFRPE, Rua Dom \\ Manoel de Medeiros, S/N Dois Irmãos, CEP 59.171-900, Recife-Brasil ${ }^{3}$ Universidade Federal de Alagoas - UFAL, \\ Br 101, Km 114 Norte Cidade Universitária, CEP 57.072-970, Maceió-Brasil
}

\begin{abstract}
The effects of thymol and carvacrol and the essential oil of Lippia gracilis on caulinary shoots of heliconia were evaluated. After disinfection, the shoots were inoculated into MS medium and subjected to the treatments with $420 \mu \mathrm{L} \mathrm{L}^{-1}$ of essential oil (EO) of L. gracilis; $420 \mu \mathrm{L} \mathrm{L}^{-1}$ of thymol; $420 \mu \mathrm{L} \mathrm{L}^{-1}$ of carvacrol; $210 \mu \mathrm{L} \mathrm{L}^{-1}$ of thymol and $210 \mu \mathrm{L} \mathrm{L}^{-1}$ of carvacrol. The control treatment consisted of the MS medium without any phytoregulators. The main components of EO from $L$. gracilis are carvacrol, $\rho$-cimene, and thymol. Seven days after the initiation of the experiments, $36.3 \%$ of the control treatment shoots were necrotized, but $90 \%$ of the caulinary shoots exposed to EO, thymol, or carvacrol appeared necrotized. Transmission electron microscopy of the shoots revealed that the treatment with EO, thymol, or carvacrol caused the destruction of the plasma cell membranes, and the cell organelles and the nucleus were hardly evident. The EO and its main constituent were toxic to caulinary shoots of heliconia.
\end{abstract}

Key words: culture in vitro, bacteria, monoterpenes, phytotoxic, antimicrobial

RESUMO: Efeito do óleo essencial de Lippia gracilis Schauer sobre ápices caulinares de heliconia cultivadas in vitro. O efeito do timol, carvacrol e óleo essencial de Lippia gracilis foi observado sobre ápices caulinares de heliconia. Após a desinfestação os ápices foram inoculados em meio MS com os tratamentos de $420 \mu \mathrm{L} \mathrm{L}-1$ do óleo essencial (OE) de L. gracilis; $420 \mu \mathrm{L} \mathrm{L}^{-1}$ de timol; $420 \mu \mathrm{L} \mathrm{L}^{-1}$ de carvacrol; $210 \mu \mathrm{g} \mathrm{L}^{-1}$ de timol e $210 \mu \mathrm{L} \mathrm{L}^{-1}$ de carvacrol. O tratamento controle consistiu de meio MS sem fitorreguladores. Os principais componentes do OE foram carvacrol, $\rho$-cimeno e timol. Sete dias após o início do experimento $36,3 \%$ dos ápices submetidos ao tratamento controle e $90 \%$ dos ápices caulinares expostos ao EO, timol ou carvacrol necrosaram. A microscopia eletrônica de transmissão dos ápices caulinares revelou que os tratamentos com OE, timol e carvacrol provocaram desestruturação da membrana plasmática das células. As organelas e o núcleo não estavam evidentes. O OE e seus principais constituintes foram tóxico para os ápices caulinares de helicônias.

Palavras-chave: cultivo in vitro, bactéria, monoterpenos, fitotoxidez, antimicrobiano

\section{INTRODUCTION}

Commercial flower markets are demonstrating a trend toward tropical species, in large part due to the durability of their inflorescences and their exotic nature. Brazil has a great large number of native species with economic potential, such as heliconia (Santos, 1999). Vegetative propagation via rhizomes is the most commonly used method for obtaining scions of heliconia. Scions currently produced through this process, however, have not kept up with consumer demands as they have a long production time, which facilitates the dissemination pathogens (Paiva, 1998).

The production of scions by in vitro culture from caulinary shoots is a viable alternative for the large scale production of certified scions. However, in vitro establishment of heliconia explants has been limited due to

Recebido para publicação em 06/12/2009

Aceito para publicação em 08/07/2011

Rev. Bras. PI. Med., Botucatu, v.14, n.1, p.26-33, 2012. 
problems of bacterial growth in the nutrient medium. Resident bacteria live symbiotically within the plant's tissues in its natural habitat (Nathan et al., 1992; Atehortua et al., 1999; Santos, 1999) but they can become pathogenic under in vitro conditions (Leifert et al., 1994). One solution for these contamination problems consists of adding antibiotics to the culture media; however, concentrations efficient against contaminants usually demonstrate phytotoxicity (Hammerschlag et al., 1997; Santos, 1999).

There has been a growing interest in the antimicrobial properties of extracts of aromatic plants, especially their essential oils (Milhau et al., 1997). The use of these products represents a new trend in agriculture and they are considered less harmful and less aggressive to both human health and the general environment (Stammati et al., 1999; Daferera et al., 2003). Thus, natural compounds extracted from medicinal plants have been replacing established and commercially available agricultural products. (Castellanos et al., 2001).

Numerous plant species produce essential oils, including Lippia gracilis Schauer (Verbenaceae) and produces high concentrations of thymol and carvacrol. The efficiency of these monoterpenes as antimicrobial agents has already been proven (Dwivedi \& Singh, 1998; Arras \& Usai, 2001; Lambert et al., 2001; Daferera et al., 2003; Pina-Vaz et al., 2004), and the use of these compounds in nutritional media could represent a viable alternative for impeding the growth of endophytic bacteria during micropropagation.

Then, the objective of the present study was to evaluate the antimicrobial effect of the essential oil of $L$. gracilis (as well as thymol and carvacrol) on caulinary shoots of Heliconia psittacorum $\times \mathrm{H}$. spathocircinata var. Golden Torch cultivated in vitro.

\section{MATERIAL AND METHOD}

\section{Extraction and Identification of chemical elements from the essential oil of Lippia gracilis}

Essential oil was obtained from the leaves of $L$. gracilis by steam extraction performed in the Organic Chemistry Laboratory of the Federal University of Pernambuco, Brazil (UFPE), using a Clevenger apparatus. After extraction, the oil was stored at low light levels at $4^{\circ} \mathrm{C}$.

Identification of the components of the essential oil of $L$. gracilis was performed in the
Fundamental Chemistry laboratory in the UFPE using a gas chromatography apparatus (GCMS QP 5050 A - Shimadzu) with a DB - 5 fused silica column (dimethylpolysiloxane) measuring $30 \mathrm{~m} \mathrm{x}$ $0.25 \mathrm{~mm}$, connected to a mass spectrometer (CG - EM), with an electronic potential of $70 \mathrm{eV}$. The dragging gas was helium $\left(1 \mathrm{~mL} \mathrm{~min}^{-1}\right)$, used at programmed temperatures (increasing at $4^{\circ} \mathrm{C}$ $\mathrm{min}^{-1}$ until reaching $180^{\circ} \mathrm{C} \mathrm{min} \mathrm{m}^{-1}$, and then $20^{\circ} \mathrm{C}$ $\mathrm{min}^{-1}$ until reaching a maximum of $280^{\circ} \mathrm{C}$ ).

Evaluation of the action of oil from Lippia gracilis (and its main components) on caulinary shoots of Heliconia psittacorum $x$ Heliconia spathocircinata var. Golden Torch

The propagating units of $H$. psittacorum $x$ H. spathocircinata var. Golden Torch (approximately $15 \mathrm{~cm}$ long) were used as the source of caulinary shoots. The shoots were disinfected with $70 \%$ alcohol for one minute, $3 \%$ calcium hypochlorite for 20 minutes, followed by three consecutive rinsings with de-ionized sterile water (DSW). MS medium (Murashige \& Skoog 1962) was used for culturing caulinary shoots without the phytoregulator to which was subsequently added $420 \mu \mathrm{L} \mathrm{L}^{-1}$ of the pure essential oil (EO) from $L$. gracilis or its main components thymol - Vetec $\left(420 \mu \mathrm{g} \mathrm{L}^{-1}\right)$; carvacrol - Aldrich $\left(420 \mu \mathrm{L} \mathrm{L}^{-1}\right)$ and thymol (210 $\left.\mu \mathrm{g} \mathrm{L}^{-1}\right)$ plus carvacrol $\left(210 \mu \mathrm{L} \mathrm{L}^{-1}\right)$. Controls consisted of MS medium without EO, thymol, or carvacrol. The concentrations of thymol and carvacrol used were based on the bactericide action of pure essential oil ( $\left.420 \mu \mathrm{L} \mathrm{L} \mathrm{L}^{-1}\right)$ observed in previous experiments.

Essential oil, thymol, and/or carvacrol were not autoclaved, but added to the MS medium after the complete fusion of agar and subsequent cooling of the media to approximately $45^{\circ} \mathrm{C}$. The $\mathrm{pH}$ was adjusted to 5.8 in all treatments. The control medium was autoclaved for 20 minutes at $120^{\circ} \mathrm{C}$.

The percentage contamination and caulinary shoot necrosis were evaluated 7 days after the initiation of the experimental regime, which included 20 repetitions per treatment. The experimental unit was one explant via tube.

Treatments were compared using the Tukey test, according to Pimentel Gomes (1985), equated for a ration comparison, considering their binomial distribution, and applying a angular transformation (arc sen $\sqrt{\% / 100}$ ) to the ratios of the results.

Histological evaluation of caulinary shoots cultivated in media with essential oil from Lippia gracilis, thymol, and/or carvacrol

Rev. Bras. PI. Med., Botucatu, v.14, n.1, p.26-33, 2012. 
Investigations using transmission electron microscopy took place in the Keizo Asami Imunopathology Laboratory (LIKA) at UFPE. Samples of caulinary shoots of $H$. psittacorum $x$ $H$. spathocircinata var. Golden Torch were treated with the essential oil of $L$. gracilis, thymol, and/or carvacrol, fixed in $2.5 \%$ glutaraldehyde $+0.1 \mathrm{M}$ phosphate buffer ( $\mathrm{pH}$ 7.2) for 8 hours, washed three times for ten minutes each in a $0.1 \mathrm{M}$ phosphate buffer and post-fixed in $1 \%$ osmium tetroxide + $0.1 \mathrm{M}$ phosphate buffer for 2 hours. Subsequently, the material was subjected to three washings of ten minutes each in $0.1 \mathrm{M}$ phosphate buffer and dehydrated in a 50, 70, 90 and $100 \%$ ethanol sequence. The samples were then immersed in 0.5: 0.5 ethanol + acetone. The material was embedded in a 3:1 mixture of acetone and SPURR resin for 8 hours; subsequently, the acetone: resin ratio was reduced to $2: 1$ and then $1: 1$ at intervals of 8 hours. The embedded material was then placed in a drying oven at $60^{\circ} \mathrm{C}$ for 72 hours. Semi-thin sections were made using a glass knife, while ultra-thin sections were prepared with a diamond knife in a Sorvall "Porter-Blum" MT 2 B ultra microtome and mounted on copper screens.

The samples were exposed to lead citrate for 5 to 10 minutes and uranyl acetate at $2 \%$ for 30 to 40 minutes for contrasting and viewed in an EM 10 (Zeiss) transmission electron microscope.

\section{RESULTS AND DISCUSSION}

The bacterial growth was observed in $53.7 \%$ of the heliconia caulinary shoots inoculated into culture media with the essential oil. This percentage is high for plant tissue culture, but tolerable in terms of heliconia micropropagation from caulinary shoots, due to the difficulty in obtaining explants without contamination by endophytic bacteria (Santos,
1999, Dias \& Rodrigues, 2001). Additionally, bacterial growth observed in treatments with the essential oil was limited to the base of the explant, and would not cause serious problems for heliconia micropropagation. However, a high percentage of necrosis was observed in caulinary shoots that had contact with the oil (Table 1). The progression of necrosis and eventual explant death were extremely fast, and could be observed two days after inoculation of the shoots.

Treatments of caulinary shoots with thymol and carvacrol (Table 1 ) resulted in bacterial growth superior to $60 \%$, which did not differ significantly from control treatments. Similar to the results observed in the essential oil treatment, bacterial growth was limited to the basal region of the shoots and these compounds also provoked necrosis of the explants. Periago et al. (2001) reported that carvacrol and thymol did not cause expressive inhibition of the growth of Bacillus cereus when they were applied separately. These compounds, which are the main components of the essential oil of $L$. gracilis, are not necessarily solely responsible for the antibacterial activity observed, and inhibition can be co-related to other constituent compounds (Rassoli \& Mirmostafa, 2003). On the other hand, other researchers have demonstrated that carvacrol used alone was more efficient against Escherichia coli, Staphylococcus aureus, S. typhii, and B. subtilis than the whole extract taken from leaves of Lippia multiflora (Kunle et al., 2003).

The control treatment culture medium appeared completely cloudy, while in treatments with essential oil, thymol, and/or carvacrol bacterial growth (when present) was limited to the explant base, indicating an effective bacteriostatic action of the $\mathrm{EO}$ and its main components.

A number of other researchers have

TABLE 1. Percentage of contamination and necrosis of caulinary shoots of Heliconia psittacorum x Heliconia spathocircinata var. Golden Torch seven days after inoculation into culture media with essential oil from Lippia gracilis, tymol, and/or carvacrol.

\begin{tabular}{lcc}
\hline Treatments & Contamination (\%) & Necrosis (\%) \\
\hline Control & $90.0 \mathrm{a}$ & $36.3 \mathrm{~b}$ \\
Tymol $\left(210 \mu \mathrm{g} \mathrm{L}^{-1}\right)+$ Carvacrol $\left(210 \mathrm{~mL} \mathrm{~L}^{-1}\right)$ & $77.1 \mathrm{a} \mathrm{b}$ & $90.0 \mathrm{a}$ \\
Carvacrol $\left(420 \mu \mathrm{L} \mathrm{L}^{-1}\right)$ & $71.6 \mathrm{a} \mathrm{b} \mathrm{c}$ & $90.0 \mathrm{a}$ \\
Tymol $\left(420 \mu \mathrm{g} \mathrm{L}^{-1}\right)$ & $63.4 \mathrm{a} \mathrm{b} \mathrm{c} \mathrm{d}$ & $90.0 \mathrm{a}$ \\
Oil $\left(420 \mu \mathrm{L} \mathrm{L}^{-1}\right)$ & $53.7 \mathrm{~b} \mathrm{c} \mathrm{d}$ & $90.0 \mathrm{a}$ \\
\hline
\end{tabular}

Averages followed by the same letters do not differ significantly by the Tukey test at $a=5 \%$. 
TABLE 2. Chemical composition of the essential oil from Lippia gracilis Schauer.

\begin{tabular}{ccc}
\hline Retention Time & Composition* $^{*}$ & Total (\%) \\
\hline 11.62 & Mircene & 3.35 \\
12.58 & Alfa - terpinene & 1.45 \\
13.00 & Para - cimene & 17.85 \\
14.25 & Gama - terpinene & 6.32 \\
18.76 & 4 - terpineol & 2.38 \\
20.9 & Timil metil ether & 4.80 \\
23.01 & Timol & 10.13 \\
23.64 & Carvacrol & 41.77 \\
25.80 & Carvacril acetate & 3.89 \\
29.46 & $3-$ tert - butil - 4 metoxiphenol & 1.65 \\
32.76 & Cariofilene oxide & 1.27 \\
\hline
\end{tabular}

${ }^{*}$ Compounds constituting less than $1 \%$ of the sample are not presented

demonstrated the antimicrobial effect of essential oils whose main components consisted of thymol and carvacrol (Dwivedi \& Singh, 1998; Arras \& Usai 2001; Demetzos et al., 2001; Lambert et al., 2001; Daferera et al., 2003; Rassoli \& Mirmostafa, 2003; Pina-Vaz et al., 2004; Sokmen et al., 2004). The present chemical analysis of essential oil from $L$. gracilis revealed high rates of the phenolic monoterpenes thymol and carvacrol, and together they represented $51.9 \%$ of the total oil content (Table 2).

Although $90 \%$ of the caulinary shoots in the control treatment demonstrated bacterial growth, only $36.3 \%$ of the shoots were necrotized seven days after the initiation of the experiment (Table 1). However, during the following days $100 \%$ of explants became necrotized. It is possible that this necrosis process resulted from phenolic compounds being released by the explants themselves, as a defense mechanism against the bacteria (Hallmann, 2001). The observed necrosis of $90 \%$ of explants exposed to essential oil, thymol, and carvacrol, could be caused by either the bacteria or the phenolic monoterpenes, or both acting together. According to Chou (1999), volatile compounds can inhibit the growth of many herbaceous plants.

Necrosis was evident in the control treatment, although the cell structures of the caulinary shoots remained intact (Figures 1, A, $B$ and $C$ ). However, the cells of caulinary shoots that had been exposed to additional treatments appeared structurally disorganized. The plasma membrane (as well as other cell membranes) in explants treated with essential oil, thymol, and/ or carvacrol were visibly disrupted (Figures 2$5)$. The chloroplasts of treated cells were not as evident as those of the controls (Figures 1, A and $C$ ), probably due to the absence of cell membranes. Fragmentation of the cell walls in explant cells treated with carvacrol created clear zones (Figure 3, B). Degradation of cell walls has been observed in food products contaminated by pathogens (Helander et al., 1998; Burt, 2004). Essential oils rich in phenolic compounds such as thymol and carvacrol exhibit strong antimicrobial activity as they provoke structural disturbances in the plasma membrane and cell walls of microorganisms (Burt, 2004). Additionally, transmission electron microscope images show coagulation of the cytoplasm in cells treated with EO (Figures 2, A, B and C), thymol (Figure $4 \mathrm{C}$ ), and thymol and carvacrol (Figures $5 \mathrm{~A}$ and $\mathrm{C}$ ). This coagulation may be the result of the spilling of cellular content, as observed by Burt (2004).

The mechanisms of volatile monoterpene action in the cells of microorganisms is well understood (Lambert et al., 2001; Burt, 2004). These effects result from the hydrophobic nature of the monoterpene (Stammati et al., 1999) that allows them to accumulate in the cell membranes. Both carvacrol and thymol associate with phospholipids in cell membranes and form channels that allow ions, enzymes, and metabolites vital to the survival of microorganisms to freely pass through them (Ultee, 2000; Burt, 2004). Due to this structural disordering of the membrane, the ATPase enzymatic complex is also disrupted, compromising the synthesis of intra cellular ATP (Burt, 2004). 

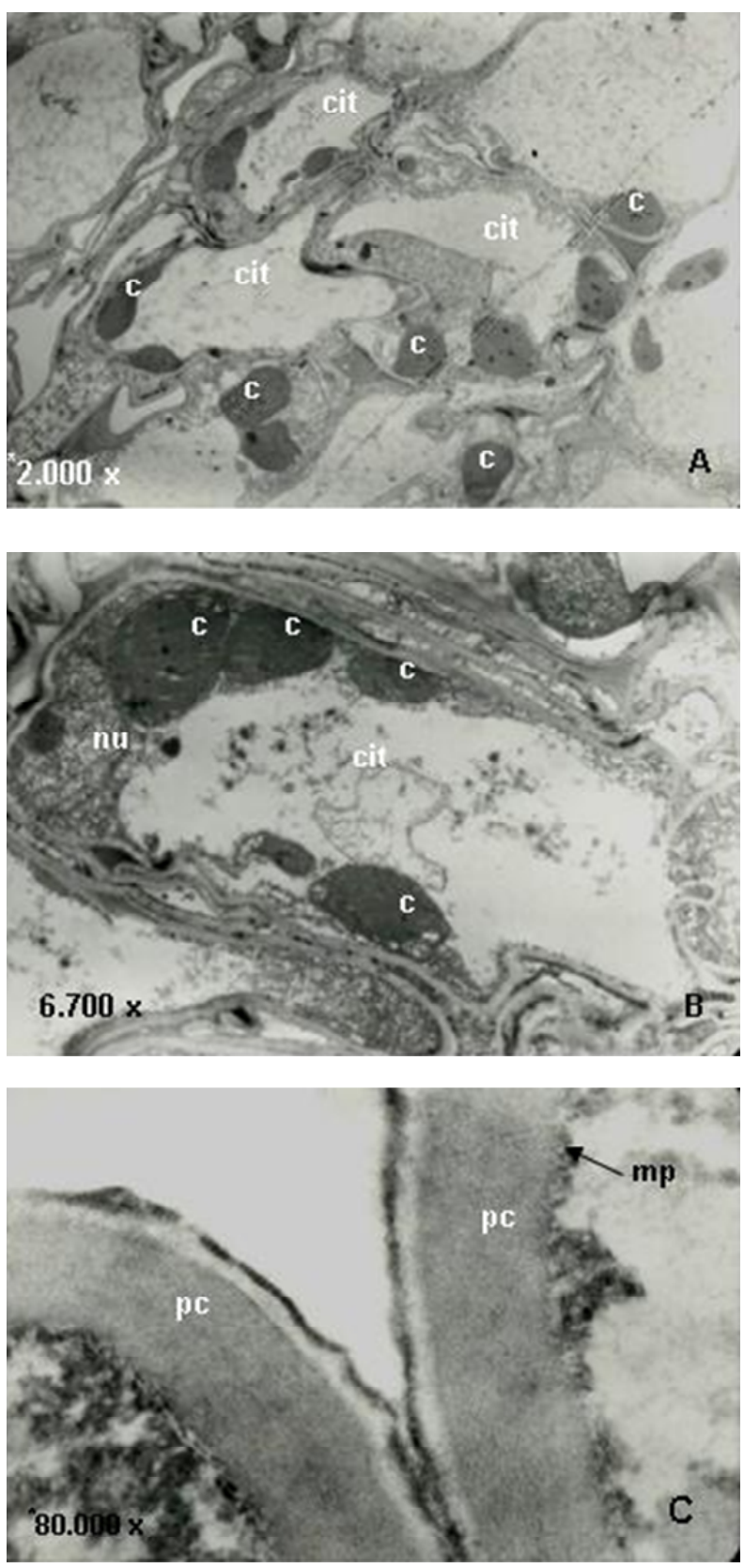

FIGURE 1. Cells of caulinary shoots of Heliconia psitacorum x Heliconia spatocircinata Goldenn Torch under control conditions. A- General view of the cells; B - Cellular unit; C - Detail of the cellular wall (c chloroplast, pc - cell wall, mp - cytoplasmic membrane, cit - cytoplasm, nu - nucleus). *Increase.

Transmission electron microscopy revealed that the effects of the EO of $L$. gracilis on heliconia caulinary shoots were similar to those previously described for microorganisms. There have been few reports on the action of volatile monoterpenes on plant cells, but research carried out with Pelargonium fragrans demonstrated that cells
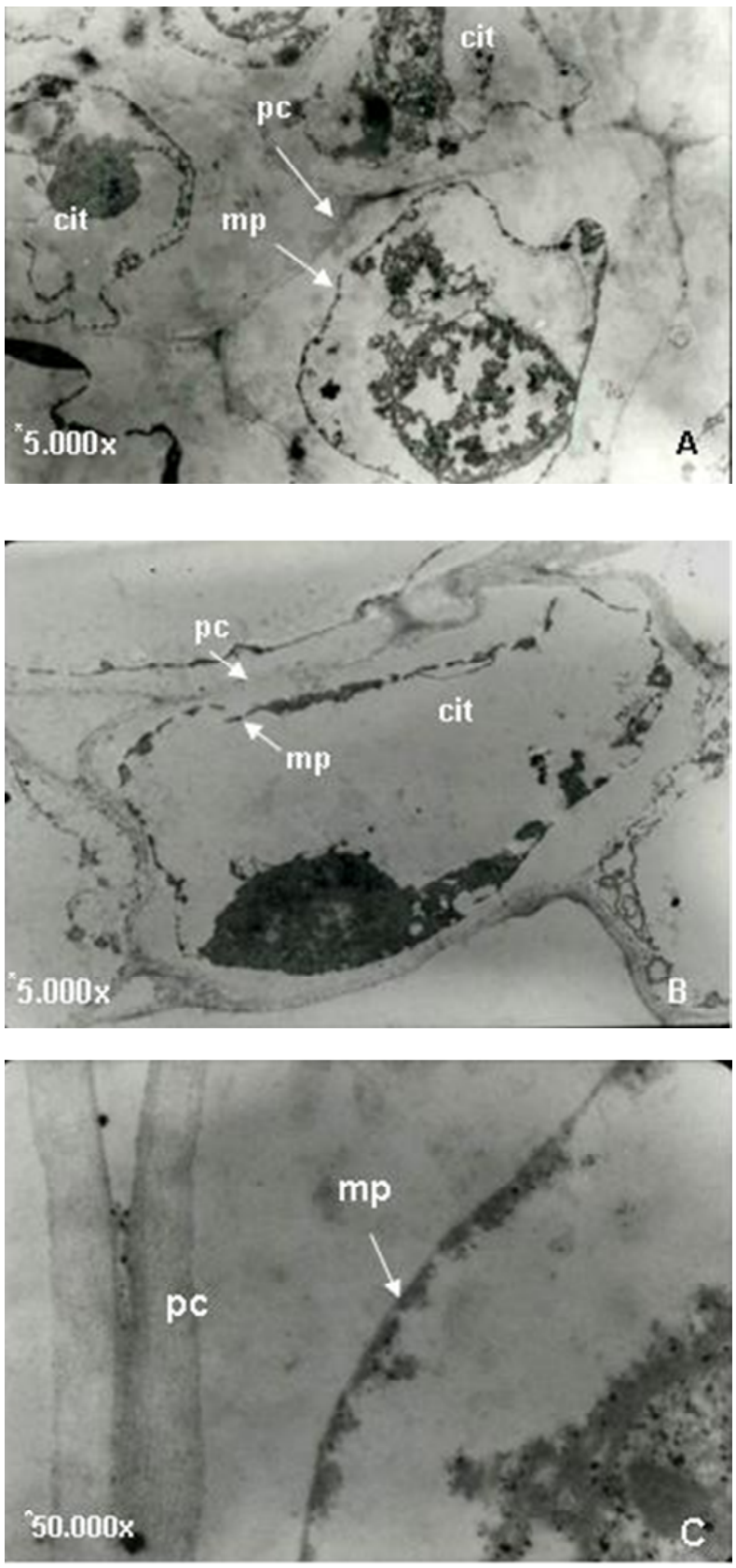

FIGURE 2. Cells of caulinary shoots of Heliconia psitacorum x Heliconia spatocircinata Golden Torch treated with the essential oil of Lippia gracilis Schauer $\left(420 \mu \mathrm{L}^{-1}\right)$. A - General view of the cells; B - Single cell; C - Detail of the cell wall ( $p c$ - cell wall, $\mathrm{mp}$ cytoplasmic membrane, cit - cytoplasm ). *Increase.

exposed to the action of phenolic monoterpenes showed structural modifications of the mitochondria and the Golgi apparatus that affected both energy transformation and protein synthesis (Brown et al., 1987).

The negative effect of EO (and its constituents) on the caulinary shoots of helicon 

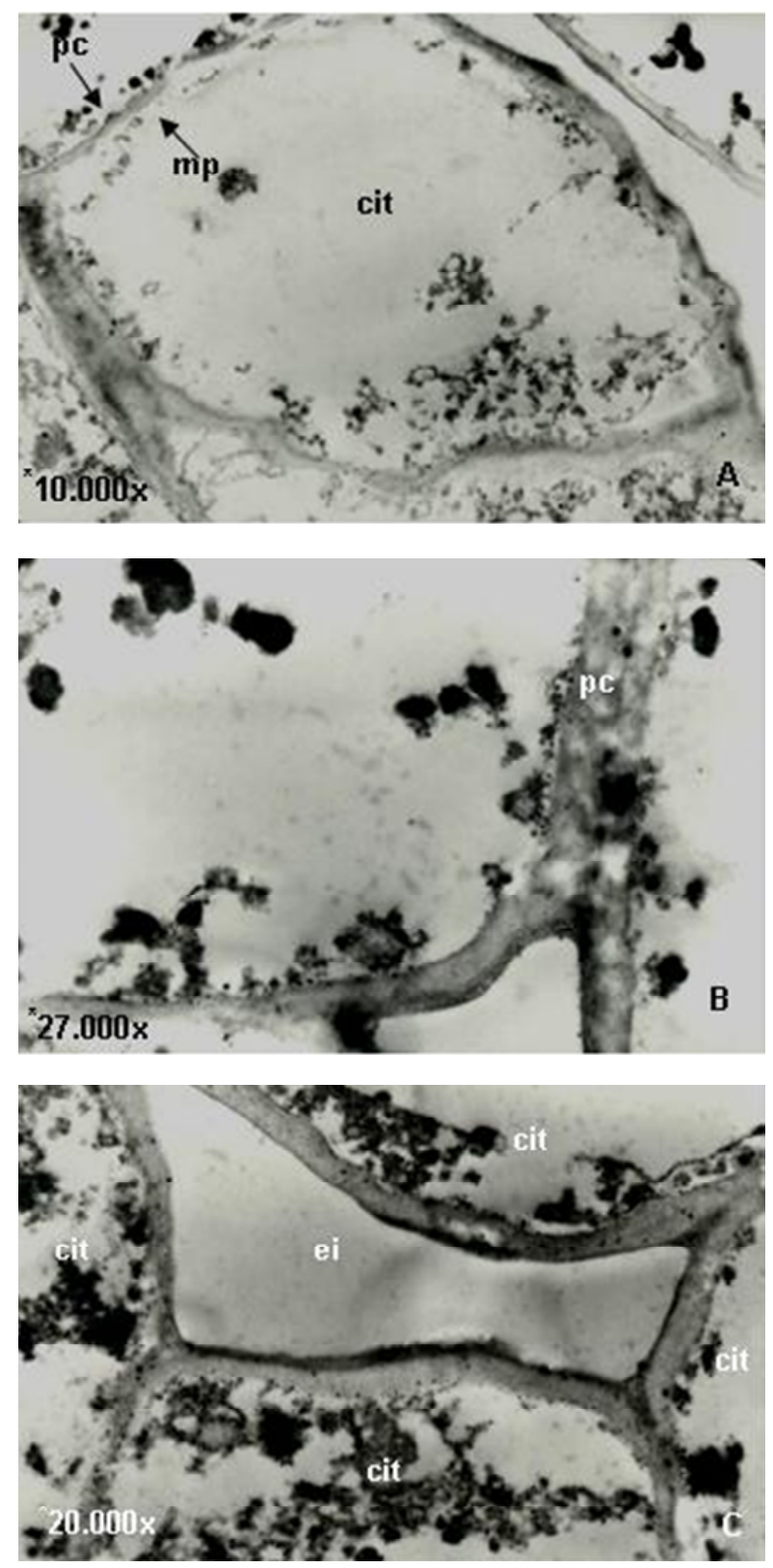

FIGURE 3. Cells of caulinary shoots of Heliconia psitacorum x Heliconia spatocircinata Golden Torch treated with carvacrol $\left(420 \mu \mathrm{L}^{-1}\right)$. A - General view of the cells; B - Single cell; C - Detail of the cell wall (pc cell wall, mp - cytoplasmic membrane, cit cytoplasm). *Increase.

may have been aggravated by the stage of development of the explants, which were in a phase of intense cell division. The cells of $P$. fragrans in a stationary developmental phase were more tolerant to the presence of phenolic monoterpenes (Brown et al., 1987). It is not known, however, if this was due to a real rise in tolerance, or simply represents a quiescent developmental stage of the cells.
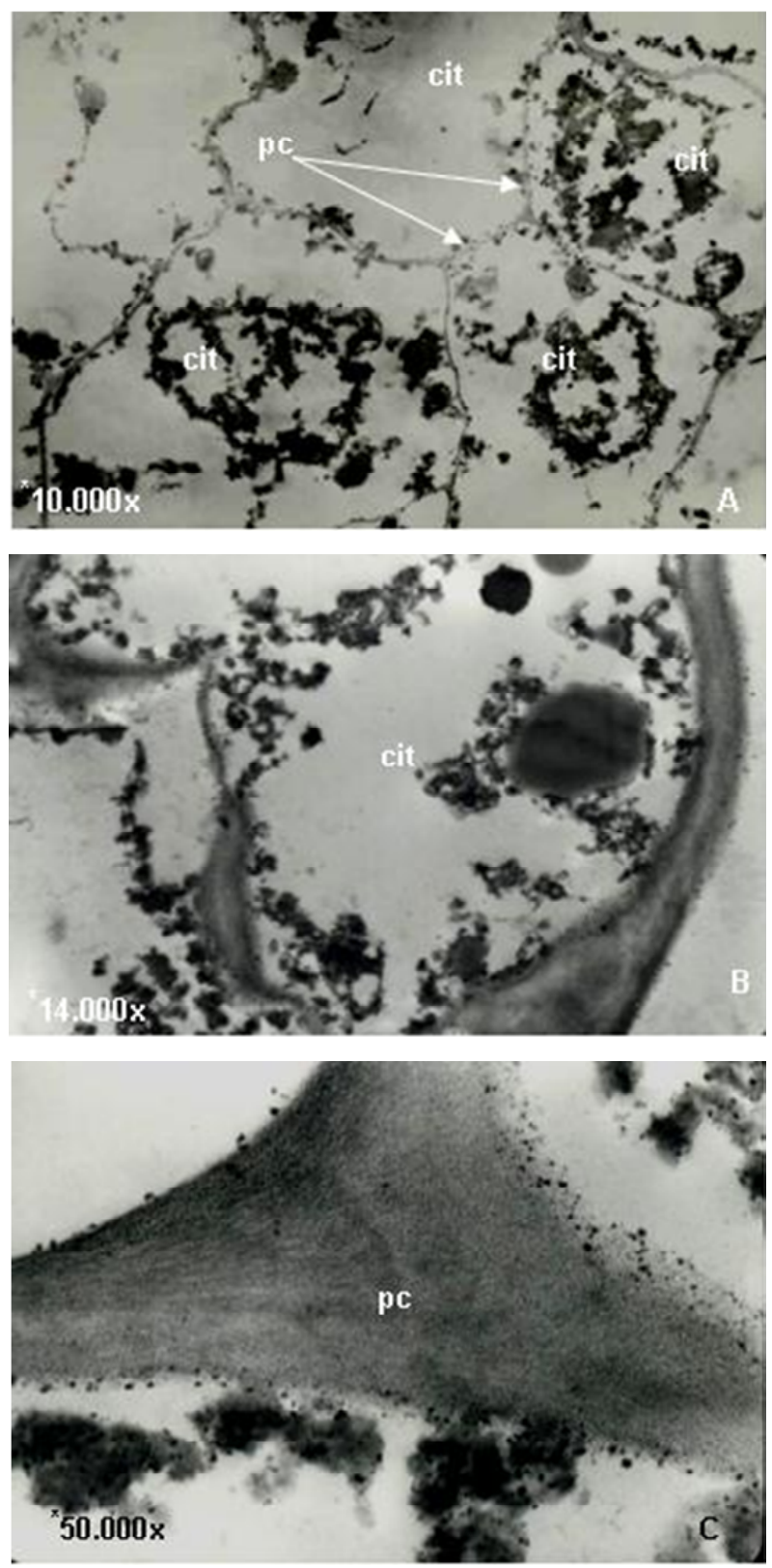

FIGURE 4. Cells of caulinary shoots of Heliconia psitacorum x Heliconia spatocircinata Golden Torch treated with tymol $\left(420 \mu \mathrm{g} \mathrm{L}^{-1}\right)$. A- General view of the cells; B - Single cell; C - Detail of the cell wall ( $p c$ cell wall, $\mathrm{mp}$ - cytoplasmic membrane, cit - cytoplasm ). *Increase.

We conclude that the essential oil of $L$. gracilis (at $420 \mathrm{~mL} \mathrm{~L}^{-1}$ ) was phytotoxic to Heliconia explants in vitro, and therefore it must not be added to the nutritional medium used for micropropagation work. However, due to its antimicrobial potential, it is recommended that this oil be further evaluated as an alternative compound for explant asepsis, as well as a hygiene product for people responsible for the manipulation of in vitro cultures. 

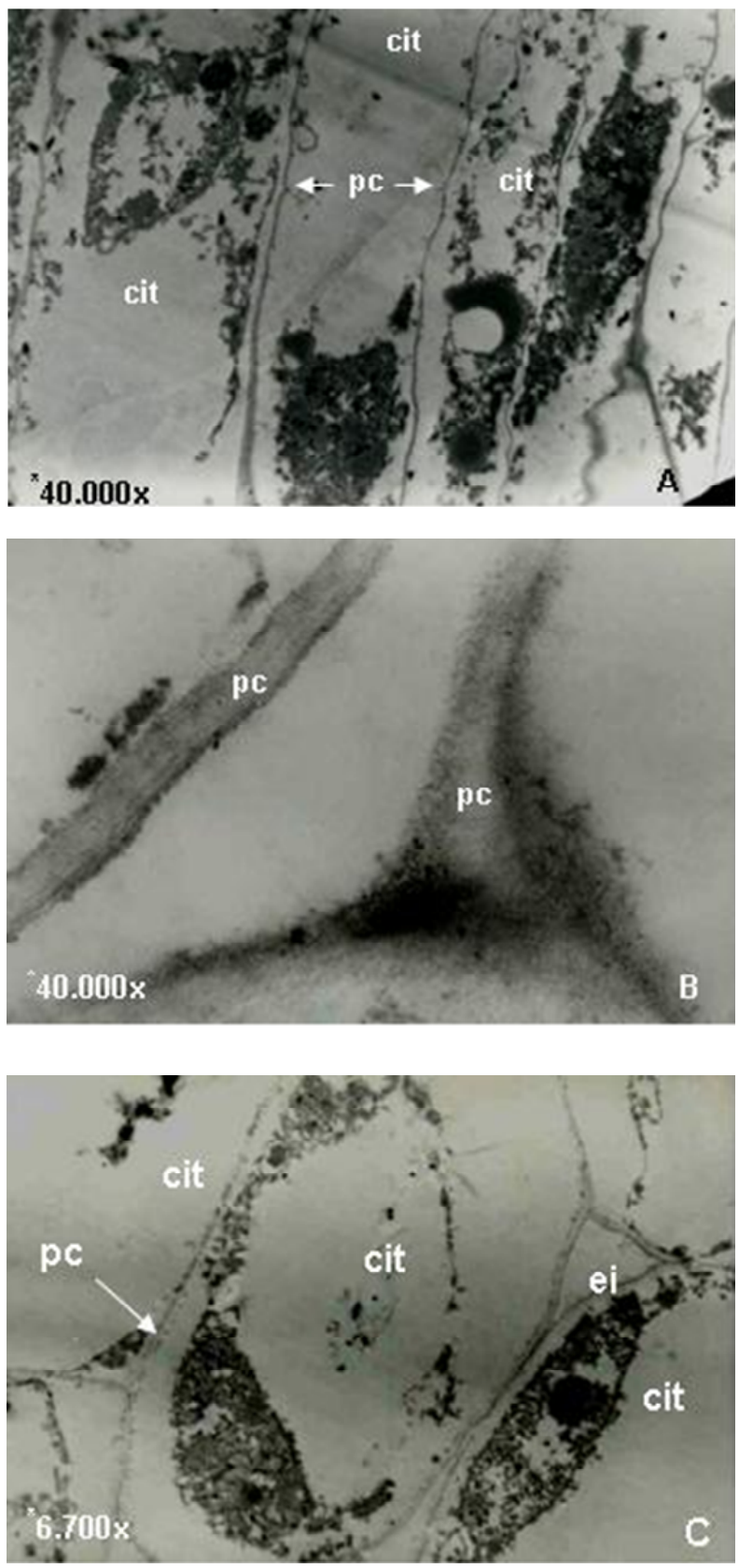

FIGURE 5. Cells of caulinary shoots of Heliconia psitacorum x Heliconia spatocircinata Golden Torch treated with tymol $\left(210 \mu \mathrm{g} \mathrm{L}^{-1}\right)$ and carvacrol $(210 \mu \mathrm{l}$ $\left.L^{-1}\right)$. A - General view of the cells; B - Detail of the cell wall; $C$ - Single cell ( $p c$ - cell wall, $\mathrm{mp}$ - cytoplasmic membrane, cit - cytoplasm, ei - intercellular space ). ${ }^{*}$ Increase.

\section{ACKNOWLEDGEMENT}

The authors would like to thank Isabelle Meunier for corrections to the statistical analyses; the Keizo Asami Immunopathology Laboratory (LIKA), for preparation of the samples for microscopic analysis; and the CNPq for their financial support.

\section{REFERENCE}

ARRAS, G.; USAI, M. Fungitoxic activity of 12 oils against four postharvest citrus pathogens: Chemical analysis of Thymus capitatus oil and its effect in subatmospheric pressure conditions. Journal of Food Protection, v.64, n.7, p.1025-9, 2001.

ATEHORTUA, L. et al. Heliconia tissue culture. The Bulletin Heliconia Society International, v.9, n.4, p.1617, 1999.

BROWN, J.; HEGARTY, P.K.; CHARDLWOOD, B.V. The toxicity of monoterpenes to plant cell cultures. Plant Science, v.48, p.195-201, 1987.

BURT, S. Essential oils: their antibacterial properties and potential applications in food - a review. International Journal of Food Microbiology, v.94, p.22353, 2004.

CASTELLANOS, P.P.; BISHOP, C.; VILLALOBOS, M.J.P. Antifungal activity of the essential oil of flowerheads of garland chrysanthemum (Chrysanthemum coronarium) against agricultural pathogens. Phytochemistry, v.57, n.1, p.99-102, 2001.

CHOU, C.H. Roles of allelopathy in plant biodiversity and sustainable agriculture. Critical Reviews in Plant Sciences, v.18, n.5, p.609-36, 1999.

DAFERERA, D.J.; ZIOGAS, B.N.; POLISSIOU, M.G. The effectiveness of plant essential oils on the growth of Botrytis cinerea, Fusarium sp. and Clavibacter michiganensis subsp. Michiganensis. Crop Protection, v.22, p.39-44, 2003.

DEMETZOS, C.; PERDETZOGLOU, D.K.; TAN, K. Composition and antimicrobial studies of the oils of Origanum calcaratum Juss. and O. Scabrum Boiss. et Heldr. form Greece. Journal of Essential Oil Research, v.13, p.460-2, 2001.

DIAS, M.; RODRIGUES, P.H.V. Fontes de explantes e contaminantes isolados em cultivo in vitro de helicônia. Revista Brasileira de Horticultura Ornamental, v.7, v.2, p.165-8, 2001.

DWIVEDI, S.K.; SINGH, K.P. Fungitoxicity of some higher plant products against Macrophomina phaseolina (Tassi) Goid. Flavour and Fragrance Journal, v.13, p.397-9, 1998.

HALLMANN, J. Plant interactions with endophytic bacteria. In: JEGER, M.J.; SPENCE, N.J.(Eds.). Biotic Interactions in Plant-Pathogen Associations. CAB International, Germany: p.87-119, 2001.

HAMMERSCHLAG, F.A. et al. Effect of antibiotics and exposure to na acidified medium on the elimination of Agrobacterium tumefaciens from apple leaf explants and on shoot regeneration. Journal of the American Society for Horticultural Science, v.122, n.6, p.758-63, 1997. HELANDER, I.M. et al. Characterization of action of selected essential oil components on Gram-negative bacteria. Journal of Agricultural and Food Chemistry, v.46, p.3590-5, 1998.

KUNLE, O. et al. Antimicrobial activity of various extracts and carvacrol from Lippia multiflora leaf extract. Phytomedicine, v.10, p.59-61, 2003.

LAMBERT, R.J.W. et al. A study of the minimum inhibitory concentration and mode of action of oregano essential oil, thymol and carvacrol. Journal of Applied Microbiology, v.91, p.453-62, 2001. 
LEIFERT, C.; MORRIS, C.E.; WAITES, W.M. Ecology of microbial saprophytes and pathogens in tissue culture and field grow plants: reasons for contamination problems in vitro. Critical Reviews in Plants Science, v.13, n.2, p.139-83, 1994.

MILHAU, G. et al. In vitro antimicrobial activity of eight essential oils. Journal Essential Oil Research, v.9, p.329-33, 1997.

MURASHIGE, T.; SKOOG, F. A revised medium for rapid growth and bioassay with tobacco tissue cultures. Physiologia Plantarum, v.15, p.473-97, 1962.

NATHAN, M.J.; GOH, C.J.; KUMAR, P.P. In vitro propagation of Heliconia psittacorum by bud culture. Hort Science, v.27, n.5, p.450-2, 1992.

PAIVA, W.O. Cultura de Helicônias. Fortaleza; EMBRAPACNPAT. (Circular Técnica, 2). 1998. 20p.

PERIAGO, P.M.; PALOP, A.; FERNÁNDEZ, P.S. Combined effect of nisin, carvacrol and thymol on the viability of Bacillus cereus heat-treated vegetative cells. Food Science Technology International, v.7, n.6, p.487-92, 2001.

PIMENTEL GOMES, F. Curso de estatística experimental. Piracicaba: Escola Superior de Agricultura Luiz de Queiroz. 1985. 466p.

PINA-VAZ, C. Antifungal activity of Thymus oils and their major compounds. Journal of the European Academy of Dermatology and Venereology, v.18, p.73-8, 2004.

RASSOLI, I.; MIRMOSTAFA, A.S. Bacterial susceptibility to and chemical composition of essential oils from Thymus kotschyanus and Thymus persicus. Journal of Agricultural and Food Chemistry, v.51, p.2200-5, 2003.

SANTOS, M.H.L.C. Avaliação do efeito de bactérias promotoras de crescimento no cultivo in vitro e em casa-de-vegetação de Heliconia psittacorum. 119p. 1999. Dissertação (Mestrado em Botânica) Universidade Federal Rural de Pernambuco, Recife.

STAMMATI, A. et al. Toxicity of selected plant volatils in microbial and mammalian short-term assays. Food and Chemical Toxicology, v.37, p.813-23, 1999.

SOKMEN, A. et al. The in vitro antimicrobial and antioxidant activities of the essential oils and methanol extracts of endemic Thymus spathulifolius. Food Control, v.15, p.627-34. 2004. ULTEE, A. Bactericidal action of carvacrol towards the food pathogen Bacillus cereus. A case study a novel approach to mild food preservations. Wageningen: Wageningen University, The Netherlands. 2000. p.97. 